\title{
KEANEKARAGAMAN HAYATI DAN ROSOT KARBON PADA RAWA-GAMBUT DI BUKIT BATU, KABUPATEN BENGKALIS, PROVINSI RIAU (Biodiversity and Carbon Sinks on Peat Swamps in Bukit Batu, Bengkalis Regency, Riau Province)
}

\author{
N.M. Heriyanto ${ }^{1^{*}}$, Dolly Priatna ${ }^{2^{*}}$, dan/and Ismayadi Samsoedin ${ }^{3}$ \\ ${ }^{1}$ Pusat Penelitian dan Pengembangan Hutan \\ Jl. Gunung Batu No.5 Po Box 165 Bogor, Jawa Barat, Indonesia \\ Telp. 0251-8633234; Fax 0251-8638111 \\ ${ }^{2}$ Program Pasca Sarjana MIPA, Jurusan Biologi, Universitas Pakuan Bogor \\ Jl. Pakuan, RT.02/RW.06, Tegallega, Kecamatan Bogor Tengah, Kota Bogor, Jawa Barat 16129 \\ Tlp (0251) 8312206 \\ ${ }^{3}$ Yayasan Sahabat Pohon Indonesia \\ Jl.Selakopi 3/IA Loji, Bogor Barat Jawa Barat \\ Telp/Fax. (0251) 8319508 \\ *Email: nurmheriyanto88@yahoo.com, dollypriatna@unpak.ac.id
}

Tanggal diterima: 30 September 2019; Tanggal direvisi: 5 Mei 2020; Tanggal disetujui: 5 Juni 2020

\begin{abstract}
Research on biodiversity and carbon sinks is still needed by the government to support policies in order to manage forests sustainably. The purpose of this study was to analyze the composition of species, stand structure, biomass and carbon sinks on peat-swamps in Bukit Batu, Bengkalis Regency, Riau Province. The research method was carried out with an inventory of vegetation to determine the potential of stands, rejuvenation, biomass and carbon sinks. Sample plots were taken randomly in the form of measuring plots of $100 \mathrm{~m} x$ $100 \mathrm{~m}$ in each condition of old secondary forest, young secondary forest and old scrub forest in the peat-swamp protection forest. The species commonly found and evenly spread in all conditions of the peat-swamp forest were Gymnacranthera paniculata, Shorea teysmanniana, and Shorea gibbosa. The structure of the third stand condition of the peatswamp forest was still like a peat-swamp natural forest with the structure of the curve was in the shape of an inverted letter "J." The three conditions of the peat-swamp forests have high biomass and carbon deposits with the highest content of those that were found in the old secondary forests, and the lowest was in the old scrub forests. The condition of the old secondary forests has the highest potential to absorb carbon dioxide in the air. The tree species that are potentially used as seed sources were $\underline{\mathrm{S}}$. teysmanniana, $\underline{\mathrm{S}}$. gibbosa and Diospyros maingayi.
\end{abstract}

Keywords: Peat, stand structure, biomass, carbon, regeneration

\section{ABSTRAK}

Penelitian keanekaragaman hayati dan rosot karbon masih diperlukan pemerintah untuk mendukung kebijakan dalam rangka mengelola hutan secara berkelanjutan. Tujuan penelitian ini adalah untuk menganalisis komposisi jenis, struktur tegakan, biomassa dan rosot karbonnya pada rawa-gambut di Bukit Batu, Kabupaten Bengkalis, Provinsi Riau. Metode penelitian dilakukan dengan cara inventarisasi vegetasi guna mengetahui potensi tegakan, permudaan, biomassa dan rosot karbon. Sampel plot diambil secara acak berupa plot berukuran $100 \mathrm{~m}$ x $100 \mathrm{~m}$ di setiap kondisi hutan sekunder tua, hutan sekunder muda dan hutan belukar tua pada hutan lindung rawa-gambut. Jenis Gymnacranthera paniculata, Shorea teysmanniana dan Shorea gibbosa ditemukan tersebar merata di setiap kondisi hutan rawa-gambut. Struktur tegakan ketiga kondisi hutan rawa-gambut masih seperti hutan alam rawa-gambut dengan kurva struktur tegakan berbentuk huruf "J" terbalik. 
Ketiga kondisi hutan rawa-gambut tersebut memiliki biomassa dan simpanan karbon yang tinggi dengan biomassa dan simpanan karbon tertinggi ada di hutan sekunder tua dan terendah di hutan belukar tua. Kondisi hutan sekunder tua berpotensi untuk menyerap karbon dioksida di udara yang tertinggi. Pohon yang potensial dijadikan sumber benih adalah pohon S. teysmanniana, S. gibbosa, dan Diospyros maingayi.

\section{Kata kunci: Biomassa, gambut, karbon, regenerasi, struktur tegakan}

\section{PENDAHULUAN}

Gambut adalah bahan tanah yang tidak mudah lapuk, yang terdiri dari bahan organik yang sebagian besar belum terdekomposisi dan terakumulasi pada keadaan anaerob. Hutan rawa gambut di Indonesia diperkirakan sekitar 14,95 juta ha tersebar di Pulau Sumatera, Kalimantan, Papua dan sebagian kecil di Sulawesi (Ripin, Astiani, \& Burhanuddin, 2017). Keberadaan hutan rawa-gambut diperkirakan 6,66 juta ha atau 44,6\% telah terdegradasi (Wahyunto, Dariah, Pitono, \& Sarwani, 2013). Salah satu penyebab degradasi lahan gambut yaitu kebakaran dan kegiatan penambangan (Masganti, Wahyunto, Dariah, Nurhayati, \& Yusuf, 2014). Degradasi akan mengakibatkan fungsi utama hutan rawa-gambut sebagai sumber keanekaragaman hayati, penyimpan karbon di alam, dan hidrologi akan terganggu.

Provinsi Riau merupakan salah satu provinsi yang paling rawan terhadap kebakaran hutan dan lahan di Indonesia, pada umumnya kebakaran tersebut berada di lahan gambut (Nurhayati, Aryanti, \& Saharjo, 2010). Luas lahan gambut di Provinsi Riau sekitar 3,89 juta ha dari 6,49 juta ha total luas lahan gambut di Pulau Sumatera. Saat ini diperkirakan lahan gambut yang telah terdegradasi sekitar 2,31 juta ha $(59,54) \%$, dan sisanya sekitar 1,04 juta ha dimanfaatkan untuk budidaya tananam seperti kelapa sawit, tanaman pangan dan hortikultura (Wahyunto et al., 2013).

Salah satu fungsi hutan yaitu sebagai penyerap (rosot) karbon dioksida $\left(\mathrm{CO}_{2}\right)$ dari udara. Di Indonesia dengan emisi $\mathrm{CO}_{2}$ terbesar terjadi tahun 2006 sebesar 195 juta ton $\mathrm{CO}_{2}{ }^{-\mathrm{e}}$. dan terendah tahun 2010 dengan 74 juta ton $\mathrm{CO}_{2}{ }^{-\mathrm{e}}$ (INCAS, 2015). Hasil penelitian Purwanta, (2010), menyatakan emisi karbon dioksida dari tahun 2001-2006 sebesar 827,06 $\mathrm{CO}_{2}$ eq $\mathrm{Gg} /$ tahun yang berasal dari proses industri atau $6 \%$ dari keseluruhan sektor yang dihitung. Untuk mengatasi masalah tersebut peran hutan sebagai penyerap $\mathrm{CO}_{2}$ harus dikelola dengan baik. Rosot karbon dioksida berhubungan erat dengan biomassa tegakan, jumlah biomassa suatu daerah diperoleh dari produksi kepadatan biomassa dan jenis pohon (Dharmawan \& Samsoedin, 2012). Emisi yang berhubungan dengan perubahan penggunaan lahan gambut dan pengelolaan lahan gambut mendekati $50 \%$ dari emisi nasional Indonesia (Rosalina, Kartawinata, Nisyawati, Nurdin, \& Supriatna, 2013).

Penelitian pendugaan biomassa dan kandungan karbon di hutan tropis masih perlu dilakukan dan dibutuhkan karena potensi biomassa hutan yang besar dalam menyerap karbon. Lebih lanjut hutan tersebut mempunyai potensi yang besar dalam pengurangan kadar $\mathrm{CO}_{2}$ melalui konservasi dan manajemen kehutanan (Laumonier, Uryu, Stuwe, Budiman, Setiabudi, \& Hadian, 2010; Yuniawati, 2013).

Tujuan penelitian adalah untuk mengetahui komposisi jenis, struktur hutan, biomassa dan rosot karbon pada kawasan hutan sekunder rawa-gambut di Bukit Batu, Kabupaten Bengkalis, Provinsi Riau. Informasi ini bermanfaat untuk rehabilitasi dan pengelolaan kawasan hutan sekunder terdegradasi. 


\section{METODOLOGI}

\section{A. Lokasi dan Waktu Penelitian}

Penelitian dilakukan pada bulan Agustus 2019 di Kelompok Hutan Bukit Batu, Kabupaten Bengkalis, Provinsi Riau. Secara administrasi lokasi penelitian ini berada di Desa Api-api dan Desa Sukajadi, Kecamatan Bandar Laksamana dan Kecamatan Bukit Batu, Kabupaten Bengkalis, Provinsi Riau.

Lokasi penelitian berada di ketinggian $\pm 15 \mathrm{~m}$ dari permukaan laut (dpl) dan merupakan bagian hutan hujan tropika rawa-gambut. Kondisi topografinya datar dengan lereng antara 0-8\%. Tanah di lokasi penelitian termasuk Tropochemist, Troposaprist dan Tropofibrist (gambut saprik) yang sudah melapuk lanjut dan bahan asal aluvium tua dengan batuan penyusunnya berupa lempung, lanau, kerikil, sisa tumbuhan dan pasir, berwarna coklat tua sampai hitam dan bila diremas kandungan seratnya kurang dari $15 \%$.

Iklim daerah ini menurut klasifikasi Schmitd \& Ferguson, termasuk tipe iklim A dengan curah hujan rata-rata per tahun $2.890 \mathrm{~mm}$, dengan hari rata-rata hujan 208 hari/tahun. Curah hujan tertinggi umumnya terjadi pada bulan Maret sebesar $146 \mathrm{~mm}$ dan terendah pada bulan Juni 38,5 $\mathrm{mm}$. Suhu udara rata-rata minimum $27,4^{\circ} \mathrm{C}$ dan maksimum $32,8^{\circ} \mathrm{C}$ dengan kelembaban udara rata-rata $79 \%$ (BPS, 2018).

\section{B. Metode}

\section{Rancangan penelitian dan pengambilan contoh}

Bahan penelitian adalah tegakan hutan berdasarkan kecerahan peta (tone) pada cita satelit dua tahun terakhir, dari citra satelit tersebut dapat dikategorikan Hutan Sekunder Tua (HST), Hutan Sekunder Muda (HSM) dan Hutan Belukar Tua (HBT) (HCS Approach Toolkit, 2017). Lokasi ini termasuk dalam Kawasan Lindung Bukit Batu, yang merupakan bagian dari kawasan hutan lindung seluas \pm 13.679 ha di Kabupaten Bengkalis, Provinsi Riau.

Plot penelitian yang berbentuk bujur sangkar seluas satu ha (Mueller-Dombois \& Ellenberg, 2016). Plot dibuat berukuran $100 \mathrm{~m} \times 100 \mathrm{~m}$ yang diletakkan secara acak di setiap kondisi tegakan dan lokasi. Luasan masing-masing lokasi satu ha untuk mewakili kondisi tegakan (Heriyanto, Samsoedin, \& Kartawinata, 2019). Di dalam plot bujur sangkar tersebut dibuat sub plot berukuran $20 \mathrm{~m}$ x $20 \mathrm{~m}$ untuk pengamatan tingkat pohon, sehingga dalam plot satu hektar terdapat 25 sub plot, dan di dalam sub plot tersebut disarangkan sub plot $5 \mathrm{~m}$ × $5 \mathrm{~m}$ untuk pengamatan tingkat pancang serta sub plot $2 \mathrm{~m} \times 2 \mathrm{~m}$ untuk tingkat semai (Gambar 1).

Tingkat pohon, pancang dan semai dalam plot direkam, dengan kriteria sebagai berikut:

1. Tingkat pohon adalah tumbuhan berkayu dengan diameter setinggi dada (diameter at breast height/dbh) $10 \mathrm{~cm}$ ke atas. Dbh diukur dari lantai hutan setinggi $130 \mathrm{~cm}$, namun jika pohon berbanir diameter diukur $20 \mathrm{~cm}$ di atas banir.

2. Tingkat pancang adalah anakan pohon atau permudaan yang tingginya $1,5 \mathrm{~m}$ ke atas dengan dbh kurang dari $10 \mathrm{~cm}$,

3. Semai adalah anakan mulai dari kecambah sampai anakan dengan tinggi kurang dari $1,5 \mathrm{~m}$.

Semua pohon dalam sub plot $(20 \mathrm{~m} \mathrm{x}$ $20 \mathrm{~m}$ ) dan pancang dalam sub plot (5 $\mathrm{m} \times 5$ $\mathrm{m})$ diukur diameter dan tingginya serta dicatat nama jenisnya. Semai dalam sub plot $2 \mathrm{~m} \times 2 \mathrm{~m}$ dihitung jumlahnya dan dicatat nama jenisnya. Contoh herbarium jenis-jenis tersebut diambil dan diidentifikasi (Wardani, Astuti, \& Heriyanto, 2017) di Laboratorium Botani dan Ekologi Hutan, Pusat Penelitian dan Pengembangan Hutan, Bogor. Tata nama jenis mengikuti The Plant List, (2013). 


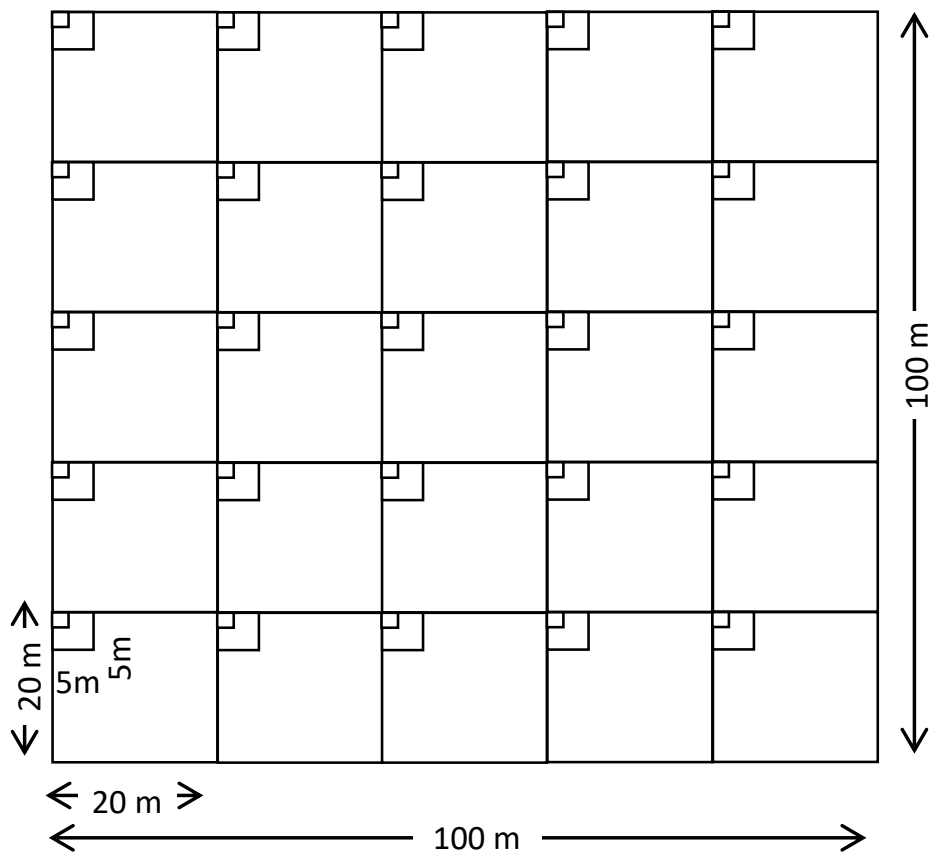

Keterangan (Remarks): Plot tingkat pohon berukuran $20 \mathrm{~m}$ x $20 \mathrm{~m}$, sub plot pancang $5 \mathrm{~m} \times 5$ $\mathrm{m}$, dan sub plot semai $2 \mathrm{~m} \times 2 \mathrm{~m}$ (Tree plots of $20 \mathrm{~m} \times 20 \mathrm{~m}, \mathrm{a}$ sapling sub plot of $5 m \times 5 m$, and a seedling sub plot of $2 m \times 2 m$ )

Gambar (Figure) 1. Bentuk plot penelitian di lapangan (Research plot form in the field)

\section{Analisis Data}

Data yang diperoleh dianalisis untuk menentukan jenis-jenis yang dominan. Jenis dominan merupakan jenis yang mempunyai nilai penting tertinggi di dalam tipe vegetasi yang bersangkutan. Jenis dominan tersebut dapat diperoleh dengan analisis indeks nilai penting (INP) sebagai penjumlahan (kerapatan relatif + dominasi relatif + frekuensi relatif) dari masing-masing jenis yang terdapat dalam sampel plot (Sadili, Kartawinata, Soedjito \& Sambas, 2018) dan untuk menghitung indeks keanekaragaman jenis tegakan (MuellerDombois \& Ellenberg, 2016).

$$
H^{\prime}=-\sum_{i=1}^{n}\left(\frac{n i}{N}\right)^{2} \log e\left(\frac{n i}{N}\right)
$$

Dimana:

$\mathrm{H}^{\prime}=$ Shanon Indeks,

$\mathrm{ni}=$ Nilai penting masing-masing spesies,

$\mathrm{e}=2,718$,

$\mathrm{N}=$ Total nilai penting
Data yang diperoleh selanjutnya dilakukan analisis, yaitu:

1. Analisis vegetasi dikelompokkan kedalam tiga tingkat perkembangan yaitu tingkat semai, pancang dan pohon yang masing-masing dihitung dalam satuan per satuan luas (ha).

2. Potensi tegakan dihitung meliputi volume tegakan dan jumlah batang per ha yang diklasifikasikan menurut kelas diameter: 10-19 cm, 20-29 cm, 30-39 cm, 40-49 cm, dan $50 \mathrm{~cm} \mathrm{ke}$ atas.

3. Pengukuran biomassa tegakan di atas permukaan tanah (above ground) menggunakan persamaan menurut Chave et al. (2014), yaitu:

$\mathrm{Y}=0,0559 \times \rho \times \mathrm{Dbh}^{2} \times \mathrm{T}$

Dimana:

$\mathrm{Y}=$ Biomassa total $(\mathrm{kg})$,

Dbh $=$ Diameter setinggi dada $(\mathrm{cm})$,

$\rho=$ Berat jenis kayu $\left(\mathrm{gr} / \mathrm{cm}^{3}\right)$,

$\mathrm{T}=$ Tinggi $(\mathrm{m})$. Rataan berat jenis kayu sebesar $0,61 \mathrm{gr} / \mathrm{cm}^{3}$. 
4. Kandungan karbon dalam vegetasi dihitung dengan menggunakan rumus (IPCC, 2013):

Kandungan karbon $=$ Berat kering tumbuhan $\mathrm{x} 50 \%$

5. Serapan karbon dioksida, dihitung dengan rumus:

Serapan karbon dioksida $\left(\mathrm{CO}_{2}\right)=$

3,67 x kandungan karbon ...........(3)

Penggunaan persamaan tersebut khusus untuk jenis-jenis yang tumbuh di hutan rawa-gambut.

\section{HASIL DAN PEMBAHASAN}

\section{Hasil}

\section{Komposisi dan potensi vegetasi}

Berdasarkan hasil identifikasi jenis dan suku tumbuhan di hutan sekunder tua, hutan sekunder muda dan belukar tua di lokasi penelitian disajikan pada Tabel 1, sedangkan kerapatan dan indeks nilai penting jenis dominan tersebut disajikan pada Tabel 2.

Pada Tabel 1 menunjukkan bahwa keadaan tegakan hutan sekunder tua lebih baik daripada hutan sekunder muda maupun hutan belukar tua. Tabel 2 menunjukkan bahwa hutan sekunder tua di Kawasan Lindung Bukit Batu, pada tingkat pohon didominasi oleh jenis pasirpasir/suntai (P. xanthochymum), dara-dara (G. paniculata), dan medang (Litsea sp.). Di hutan sekunder muda jenis dominan adalah meranti sapat (S. dasyphylla), jambu-jambu (Eugenia sp.), dan dara-dara (G. paniculata). Di belukar tua didominasi oleh jenis pisang-pisang (D. maingayi), meranti bunga (S. teysmanniana) dan medang (L. firma).

\section{Struktur tegakan dan regenerasi}

Struktur tegakan hutan adalah sebaran individu tumbuhan dalam lapisan tajuk dan dapat diartikan sebaran pohon per satuan luas dalam berbagai kelas diameternya.

Pada Gambar 2a (hutan sekunder tua) peubah tinggi didominasi oleh jenis pasirpasir (P. xanthochymum), meranti bunga (S. teysmanniana) dan pisang-pisang (D. maingayi). Gambar $2 \mathrm{~b}$ (hutan sekunder muda) didominasi oleh jenis meranti sapat (S. dasyphylla), pasir-pasir (P. xanthochymum) dan balam putih (M. ovata), Di hutan belukar tua (Gambar 2c) didominasi oleh jenis meranti bunga (S. teysmanniana), pisang-pisang (D. maingayi) dan pasir-pasir (P. xanthochymum).

Tabel (Table) 1. Jumlah suku, jenis, pohon, dan volume tegakan per ha di lokasi penelitian (Number of families, species, trees, and volume per ha at the study sites)

\begin{tabular}{lcccc}
\hline Tipe hutan (Forest type) & $\begin{array}{c}\text { Jumlah suku } \\
\text { (Number of } \\
\text { family) }\end{array}$ & $\begin{array}{c}\text { Jumlah jenis } \\
\text { (Number of } \\
\text { species) }\end{array}$ & $\begin{array}{c}\text { Jumlah pohon } \\
\text { (Number of } \\
\text { trees) } \\
\text { (Pohon/ha) } \\
(\text { Trees/ha) }\end{array}$ & $\begin{array}{c}\text { Volume } \\
\text { tegakan } \\
\text { (Volume of } \\
\text { stands) }\left(\mathrm{m}^{3} / \mathrm{ha}\right)\end{array}$ \\
\hline $\begin{array}{l}\text { 1. Hutan sekunder tua (Old } \\
\text { secondary forest) }\end{array}$ & 22 & 40 & 528 & 259,88 \\
$\begin{array}{l}\text { 2. Hutan sekunder muda } \\
\text { (Young secondary forest) }\end{array}$ & 18 & 45 & 379 & 131,89 \\
$\begin{array}{l}\text { 3. Belukar tua (Old scrub } \\
\text { forest) }\end{array}$ & 20 & 35 & 348 & 110,48 \\
\hline
\end{tabular}


Tabel (Table) 2. Jenis-jenis pohon dominan berdiameter $10 \mathrm{~cm}$ ke atas di hutan sekunder rawa-gambut, Kabupaten Bengkalis (The dominant tree species diameter $10 \mathrm{~cm}$ and above in the secondary peat-swamps forests, Bengkalis Regency)

\begin{tabular}{lcc}
\hline \multicolumn{1}{c}{ Tipe hutan (Forest type) } & $\begin{array}{c}\text { Kerapatan } \\
\text { (Density) } \\
\text { (Pohon/ha) } \\
\text { (Trees/ha) }\end{array}$ & $\begin{array}{c}\text { Indeks nilai } \\
\text { penting } \\
\text { (Importance } \\
\text { value index) } \\
(\%)\end{array}$ \\
\hline A. Hutan sekunder tua (Old secondary forests): & & \\
1. Pasir-pasir/suntai (Palaquium xanthochymum (de Vriese) & 116 & 67,46 \\
Pierre) & & \\
2. Dara-dara (Gymnacranthera paniculata Warb.) & 19 & 33,06 \\
3. Medang (Litsea sp.) & 37 & 18,72 \\
4. Meranti bunga (Shorea teysmanniana Dyer.) & 23 & 14,81 \\
5. Meranti sapat (Shorea gibbosa Brandis.) & 26 & 14,36 \\
6. Arang-arang (Diospyros siamang Bakh.) & 32 & 13,94 \\
B. Hutan sekunder muda (Young secondary forests): & & \\
1. Meranti sapat (Shorea dasyphylla Foxw.) & 73 & 47,20 \\
2. Jambu-jambu (Eugenia sp.) & 40 & 27,20 \\
3. Dara-dara (Gymnacranthera paniculata Warb.) & 35 & 25,06 \\
4. Pasir-pasir/suntai (Palaquium xanthochymum (de Vriese) & 12 & 19,84 \\
Pierre) & & \\
5. Meranti bunga (Shorea teysmanniana Dyer.) & 27 & 17,83 \\
6. Pisang-pisang (Diospyros maingayi (Heiren) Bakh.) & 19 & 16,98 \\
C. Belukar tua (Old bushes): & & \\
1. Pisang-pisang (Diospyros maingayi (Heiren) Bakh.) & 29 & 26,72 \\
2. Meranti bunga (Shorea teysmanniana Dyer.) & 28 & 22,37 \\
3. Medang (Litsea firma Hook.f.) & 29 & 21,62 \\
4. Akasia (Acacia crassicarpa A.Cunn. ex Benth.) & 11 & 20,03 \\
5. Dara-dara (Gymnacranthera paniculata Warb.) & 25 & 19,78 \\
6. Geronggang (Cratoxylon arborescens Bl.) & 24 & 18,58 \\
\hline
\end{tabular}

Hasil penelitian sebaran semua pohon untuk kelas diameter 10-19 cm, 20-29 cm, 30-39 cm, 40-49 cm, dan $50 \mathrm{~cm} \mathrm{ke}$ atas pada kawasan hutan rawa-gambut di Kabupaten Bengkalis disajikan pada Gambar 3. Struktur tegakan hutan tidak selalu sama walaupun di tempat yang sama, hal ini disebabkan oleh adanya perbedaan kemampuan pohon dalam memanfaatkan energi matahari, unsur hara/mineral dan air, serta sifat kompetisi.
Adanya kegiatan penebangan, kebakaran, tumbang (bencana alam) atau mati secara fisiologis, hal ini akan terjadi proses regenerasi. Regenerasi merupakan fenomena alam dimana pohon yang muda akan menggantikan pohon dewasa karena sesuatu sebab. Adapun regenerasi jenis tumbuhan lengkap (ada di setiap tingkat pohon, pancang dan semai untuk setiap kondisi hutan pada hutan rawa-gambut di Kabupaten Bengkalis, Provinsi Riau disajikan pada Tabel 3. 


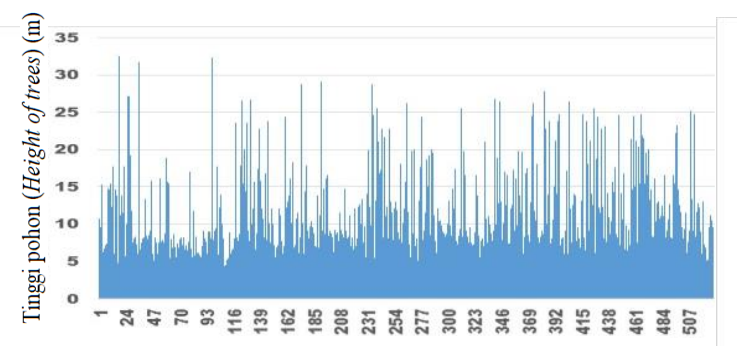

(a)

Nomor pohon (Number of trees)

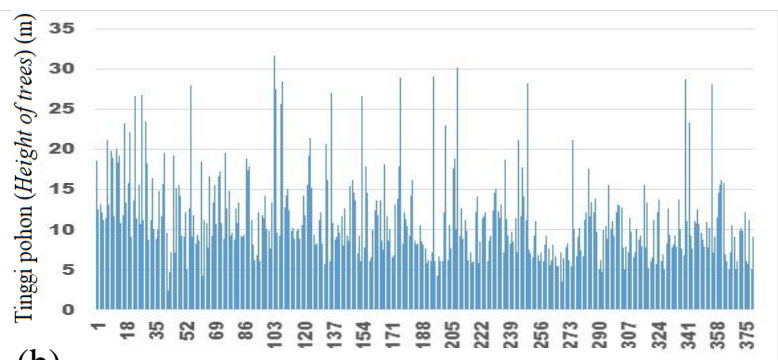

(b)
Nomor pohon (Number of trees)

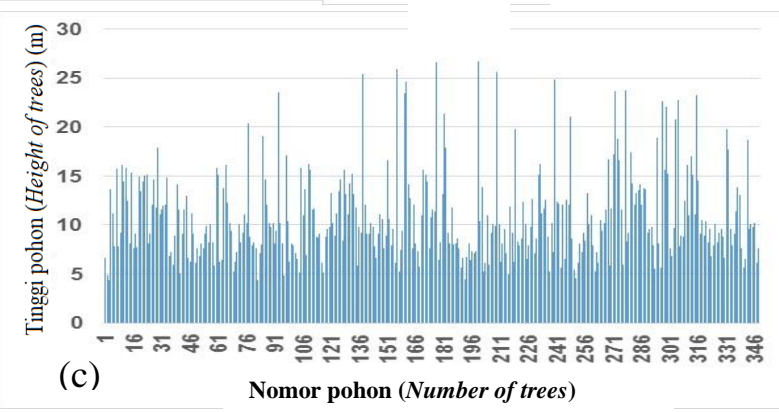

Gambar (Figure) 2. Profil tegakan hutan di lokasi penelitian: (a) Hutan sekunder tua, (b) Hutan sekunder muda, dan (c) Hutan belukar tua (Diagram profile of forest stands in the study sites: (a) Old secondary forest, (b) Young secondary forest, and (c) Old scrub forest)

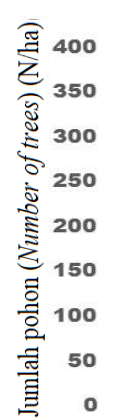

(a)

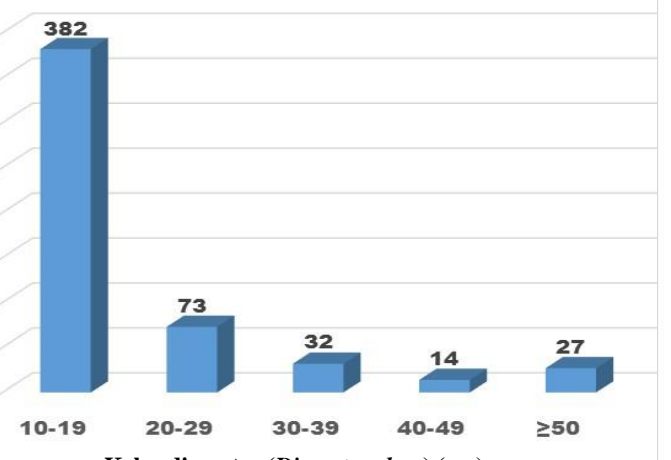

Kelas diameter (Diameter class) (cm)

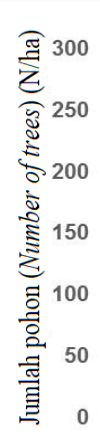

(b)

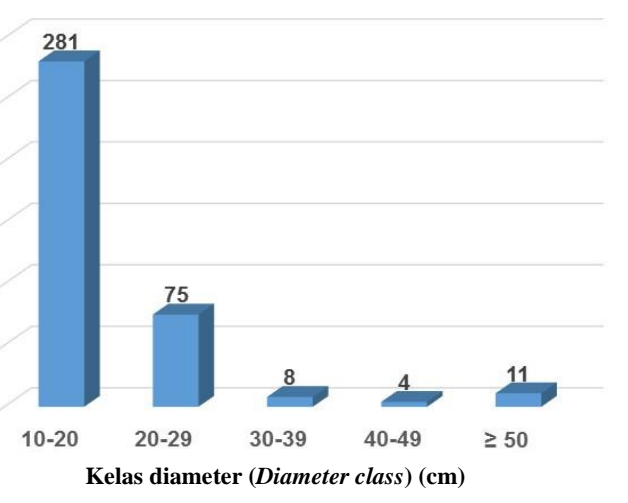

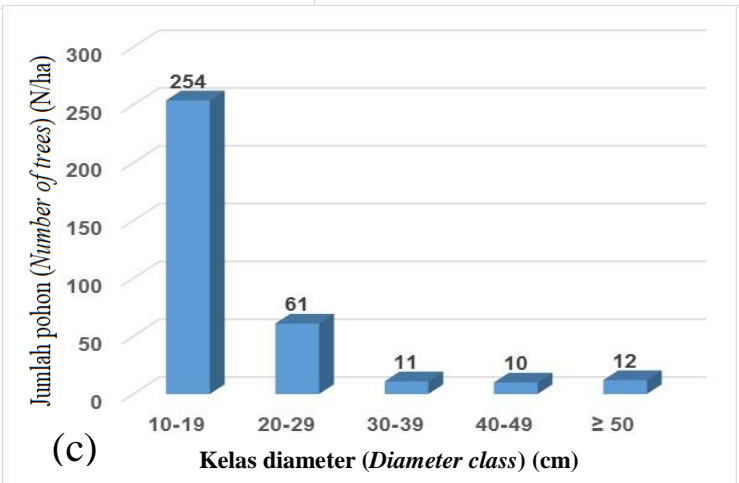

Gambar (Figure) 3. Struktur tegakan pohon berdasarkan hubungan antara kelas diameter dengan jumlah pohon di lokasi penelitian: (a) Hutan sekunder tua, (b) Hutan sekunder muda, dan (c) Hutan belukar tua (Tree stand structure based on the relationship between diameter classes and number of trees at the study sites: (a) Old secondary forest, (b) Young secondary forest, and (c) Old scrub forest) 
Tabel 3 menunjukkan bahwa jenis yang mendominasi regenerasi (tingkat pohon, pancang dan semai) yang menyebar di setiap lokasi yaitu jenis dara-dara (G. paniculata), arang-arang (D. siamang) dan jambu/kelat (Eugenia sp.). Kerapatan tingkat pancang untuk jenis komersial dan semua jenis sebesar 2.192 batang/ha dan 2.656 batang/ha. Kerapatan tingkat semai untuk jenis komersial dan semua jenis sebesar 12.800 batang/ha dan 20.000 batang/ha.

\section{Biomassa dan kandungan karbon}

Pada Tabel 4, terlihat bahwa biomassa dan kandungan karbon tegakan hutan yang berdiameter $10 \mathrm{~cm}$ ke atas di Kawasan Lindung Bukit Batu, Kabupaten Bengkalis, Provinsi Riau untuk hutan sekunder tua termasuk tinggi sebesar 302,29 ton/ha (151,14 ton $\mathrm{C} /$ ha setara dengan 554,70 ton $\mathrm{CO}_{2} /$ ha) dan terendah adalah hutan belukar tua dengan biomassa dan kandungan karbon sebesar 72,75 ton/ha $(36,37$ ton $\mathrm{C} /$ ha setara dengan 133,50 ton $\mathrm{CO}_{2} / \mathrm{ha}$ ).

\section{B. Pembahasan}

\section{Komposisi dan potensi vegetasi}

Pada Tabel 1, dapat dikemukakan bahwa jenis dan suku yang paling dominan di hutan lindung rawa-gambut sekunder tua yaitu jenis pasir-pasir/suntai (P. xanthochymum) dari suku Sapotaceae dengan INP 67,46\%; di hutan sekunder muda adalah jenis meranti sapat (S. dasyphylla) dari suku Dipterocarpaceae dengan INP 47,20\%, dan di hutan belukar tua adalah jenis pisang-pisang (D. maingayi) dari suku Ebenaceae dengan INP $26,72 \%$. Hasil penelitian menunjukkan dari tiga lokasi tipe hutan tersebut terdapat enam jenis pohon dominan berdiameter $\geq 10 \mathrm{~cm}$ dengan INP $>10 \%$.

Tabel (Table) 3. Indeks nilai penting (INP) jenis pohon dengan regenerasi lengkap dalam tiga tegakan hutan di lokasi penelitian (Important value index (IVI) of tree species with complete regeneration in the three forest stands at the study sites)

\begin{tabular}{|c|c|c|c|c|}
\hline \multirow[b]{2}{*}{ Tipe hutan (Forest type) } & \multirow[b]{2}{*}{ Suku (Family) } & \multicolumn{3}{|c|}{$\operatorname{INP}(I V I)(\%)$} \\
\hline & & $\begin{array}{c}\text { Semai } \\
(\text { Seedlings })\end{array}$ & $\begin{array}{l}\text { Pancang } \\
\text { (Saplings) }\end{array}$ & $\begin{array}{l}\text { Pohon } \\
\text { (Trees) }\end{array}$ \\
\hline \multicolumn{5}{|l|}{ A. Hutan sekunder tua (Old secondary forest): } \\
\hline $\begin{array}{l}\text { 1. Bintangur (Calophyllum sclerophyllum } \\
\text { Vesque) }\end{array}$ & Guttiferae & 6,67 & 3,53 & 1,75 \\
\hline $\begin{array}{l}\text { 2. Pisang-pisang (Diospyros maingayi } \\
\text { (Heiren) Bakh.) }\end{array}$ & Ebenaceae & 1,89 & 2,02 & 4,89 \\
\hline 3. Arang-arang (Diospyros siamang Bakh.) & Ebenaceae & 6,28 & 32,96 & 13,94 \\
\hline 4. Jambu-jambu/kelat (Eugenia sp.) & Myristicaceaee & 15,44 & 12,34 & 10,83 \\
\hline 5. Asam kandis (Garcinia nervosa Miq.) & Guttiferae & 1,89 & 20,32 & 10,14 \\
\hline $\begin{array}{l}\text { 6. Samak (Glochidion superbum Baillon. Ex } \\
\text { Müll. Arg.) }\end{array}$ & Euphorbiaceae & 8,56 & 12,45 & 9,04 \\
\hline $\begin{array}{l}\text { 7. Dara-dara (Gymnacranthera paniculata } \\
\text { Warb.) }\end{array}$ & Myristicaceaee & 10,56 & 10,65 & 33,06 \\
\hline \multicolumn{5}{|c|}{ B. Hutan sekunder muda (Young secondary forest): } \\
\hline 1. Arang-arang (Diospyros siamang Bakh.) & Ebenaceae & 3,95 & 3,96 & 4,41 \\
\hline 2. Jambu-jambu (Eugenia sp.) & Myristicaceae & 9,29 & 59,27 & 27,20 \\
\hline $\begin{array}{l}\text { 3. Dara-dara (Gymnacranthera paniculata } \\
\text { Warb.) }\end{array}$ & Myristicaceae & 56,20 & 27,18 & 25,06 \\
\hline $\begin{array}{l}\text { 4. Pelam/mangga hutan (Mangifera } \\
\text { parvifolia Boerl. \& Koord.) }\end{array}$ & Anacardiaceae & 3,95 & 10,08 & 7,39 \\
\hline
\end{tabular}


Tabel (Table) 3. Lanjutan (Continuation)

\begin{tabular}{|c|c|c|c|c|}
\hline \multirow[b]{2}{*}{ Tipe hutan (Forest type) } & \multirow[b]{2}{*}{ Suku (Family) } & \multicolumn{3}{|c|}{$\operatorname{INP}(I V I)(\%)$} \\
\hline & & $\begin{array}{c}\text { Semai } \\
\text { (Seedlings) }\end{array}$ & $\begin{array}{l}\text { Pancang } \\
\text { (Saplings) }\end{array}$ & $\begin{array}{l}\text { Pohon } \\
\text { (Trees) }\end{array}$ \\
\hline 5. Mensiro (Mezzetia leptopoda Oliv.) & Annonaceae & 36,22 & 28,10 & 11,87 \\
\hline 6. Pelawan (Tristania maingayi Duthie) & Myrtaceae & 12,07 & 14,23 & 3,71 \\
\hline 7. Kelat (Xylopia sp.) & Annonaceae & 33,23 & 27,31 & 4,77 \\
\hline \multicolumn{5}{|l|}{ C. Belukar tua (Old bushes): } \\
\hline $\begin{array}{l}\text { 1. Bintangur (Calophyllum sclerophyllum } \\
\text { Vesque.) }\end{array}$ & Guttiferae & 8,07 & 19,73 & 0,97 \\
\hline 2. Arang-arang (Diospyros siamang Bakh.) & Ebenaceae & 5,16 & 15,99 & 11,80 \\
\hline $\begin{array}{l}\text { 3. Asam keranji (Dialium platysepalum } \\
\text { Baker) }\end{array}$ & Leguminosae & 5,82 & 18,14 & 0,95 \\
\hline 4. Jambu-jambu/Cemeti (Eugenia sp.) & Myrtaceae & 19,70 & 26,97 & 15,94 \\
\hline 5. Pelawan (Evodia aromatica $\mathrm{B} 1)$. & Myrtaceae & 4,03 & 3,68 & 0,93 \\
\hline $\begin{array}{l}\text { 6. Dara-dara (Gymnacranthera paniculata } \\
\text { Warb.) }\end{array}$ & Myristicaceae & 34,51 & 17,37 & 19,78 \\
\hline 7. Medang (Litsea firma) & Lauraceae & 2,91 & 7,87 & 21,62 \\
\hline
\end{tabular}

Tabel (Table) 4. Dugaan biomassa, kandungan karbon, dan serapan karbon dioksida dalam hutan di lokasi penelitian (Estimate of biomass, carbon content and carbon dioxide uptake in the forests at the research sites)

\begin{tabular}{lllc}
\hline \multicolumn{1}{c}{ Tipe hutan (Forest type) } & $\begin{array}{c}\text { Biomassa } \\
\text { (Biomass) } \\
\text { (ton/ha) }\end{array}$ & $\begin{array}{c}\text { Karbon } \\
\text { (Carbon) } \\
\text { (ton C/ha) }\end{array}$ & $\begin{array}{c}\text { Karbon dioksida } \\
\text { (Carbon dioxide) } \\
\left.\text { (ton CO } \mathrm{CO}_{2} / \mathrm{ha}\right)\end{array}$ \\
\hline $\begin{array}{l}\text { 1. Hutan sekunder tua (Old secondary } \\
\text { forest) }\end{array}$ & 302,29 & 151,14 & 554,70 \\
$\begin{array}{l}\text { 2. Hutan sekunder muda (Young secondary } \\
\quad \text { forest) }\end{array}$ & 86,86 & 43,42 & 159,38 \\
\begin{tabular}{l} 
3. Belukar tua (Old scrub forest) \\
\hline
\end{tabular} & 72,75 & 36,37 & 133,50 \\
\hline
\end{tabular}

Hasil penelitian Rosalina, Kartawinata, Nisyawati, Nurdin, \& Supriatna, (2014), di hutan primer rawagambut Selat Panjang, Riau, dalam plot satu ha ditemukan 49 jenis pohon, 30 suku dan jumlah pohon berdiameter $10 \mathrm{~cm}$ ke atas sebanyak 550 pohon/ha, dua jenis pohon dominan yaitu P. atrocarpus (INP = $45,86 \%)$ dan B. subrotundifolium (INP $=$ 22,46\%). Heriyanto et al., (2019), melaporkan hasil penelitian di hutan rawagambut Dumai, Provinsi Riau, dijumpai 32 jenis pohon berdiameter $10 \mathrm{~cm}$ ke atas berjumlah 354 pohon/ha dan 22 suku, jenis terbanyak dari suku Dipterocarpaceae. Penelitian tersebut tidak terlalu berbeda dengan penelitian ini di hutan sekunder tua yaitu sebanyak 40 jenis pohon/ha, 22 suku dan 528 pohon/ha diameter $10 \mathrm{~cm}$ ke atas. Hal ini diduga peran pemerintah daerah
(Dinas Kehutanan) setempat dan masyarakat peduli lingkungan yang menjaga hutan rawa gambut ini dari perambahan dan kebakaran. Pohon dengan INP di atas 15\% (Arbainsyah, De longh, \& Kustiawan, 2014) menandakan jenis tersebut dapat dijumpai di lokasi dengan mudah. Oleh karena itu, pohon tersebut dapat dijadikan sumber benih untuk merestorasi hutan gambut yang terdegradasi.

Pada Tabel 2, di hutan sekunder tua Kawasan Lindung Bukit Batu, Kabupaten Bengkalis, Provinsi Riau bahwa potensi tegakan untuk $10 \mathrm{~cm}$ ke atas yang potensi tegakannya tertinggi ada di hutan sekunder tua dan terendah di hutan belukar tua. Di hutan sekunder muda didominir oleh meranti sapat (S. dasyphylla), jambujambu (Eugenia sp.) dan dara-dara 
(G. paniculata). Di belukar tua didominasi oleh jenis pisang-pisang (D. maingayi), meranti bunga (S. teysmanniana) dan medang (L. firma). Indeks keragaman (H') jenis tegakan di masing-masing tipe hutan tergolong kategori sedang dengan nilai indeks keragaman sebesar 2,93 di sekunder tua; 3,06 di sekunder muda, dan 3,10 di belukar tua. Jenis pohon dominan yang selalu ada di ketiga kondisi hutan rawa gambut tersebut adalah dara-dara (G. paniculata) dengan kerapatan tegakan antara 19-35 pohon/ha dan meranti bunga (S. teysmanniana) antara 23-28 pohon/ha. Dengan demikian, jenis pohon dara-dara dan meranti bunga menunjukkan kerapatannya cukup tinggi dan menyebar secara merata di ketiga kondisi hutan rawa gambut. Kerapatan tegakan dan sebaran jenis pohon merupakan salah satu petunjuk kekayaan hayati pada kawasan hutan (Rosalina et al., 2013 \& 2014; Samsoedin, Heriyanto, \& Bismark, 2014).

Jenis yang potensial menggantikan tegakan yang akan datang di hutan sekunder tua rawa gambut yaitu tegakan tingkat pancang yaitu jenis pasir-pasir (P. xanthochymum) dengan INP $=38,80 \%$, arang-arang (D. siamang) $(\mathrm{INP}=32,96 \%)$ dan mensiro (M. leptopoda) (INP = $25,09 \%$ ). Pada hutan sekunder muda rawa gambut adalah jenis jambu-jambu (Eugenia sp.) dengan INP $=59,27 \%$, tulang-tulang ( $\mathrm{S}$. clavimyrtus) (INP = 39,39\%) dan mensiro (M. leptopoda) (INP $=28,10 \%$ ). Pada belukar tua hutan rawa gambut ialah jenis tulang-tulang (S. clavimyrtus) dengan INP $=48,65 \%$, kelat (Xylopia sp.) $(\mathrm{INP}=41,45 \%)$ dan jambujambu (Eugenia sp.) (INP = 26,97\%).

Pohon dara-dara dan meranti bunga yang mendominasi di ketiga tipe hutan termasuk jenis komersial, kegunan kayu tersebut sebagai kayu bangunan, perabot rumah tangga dan kayu lapis (Supriadi \& Abdurachman, 2018). Silvikultur kedua jenis tersebut sudah dikuasai oleh masyarakat maupun instansi terkait/Dinas Kehutanan. Menurut informasi dari Dinas
Kehutanan Provinsi Riau, jenis meranti bunga lebih tersebar merata di banding jenis dara-dara di hutan rawa-gambut di provinsi tersebut, akan tetapi untuk keperluan pengkayaan jenis dapat dipilih dara-dara.

\section{Struktur tegakan dan regenerasi}

Secara keseluruhan struktur tegakan pohon menurut tingginya di tiga tipe hutan rawa-gambut di Kabupaten Bengkalis, Provinsi Riau sebagai berikut:

(a) Di hutan sekunder tua (Gambar 2a) jenis pohon menjulang (tinggi pohon lebih dari $30 \mathrm{~m}$ ) didominasi oleh pohon pasir-pasir (P. xanthochymum), meranti bunga (S. teysmanniana dan pisang-pisang (D. maingayi). Jenis yang tingginya antara 20-29 m didomi-nasi pohon jangkang (D. pulchella), meranti sapat (S. gibbosa) dan meranti bunga (S. teysmanniana). Tinggi pohon kurang dari $20 \mathrm{~m}$ didominasi oleh pohon jambu-jambu (Eugenia sp.), milas (L. multinervium) dan pasir-pasir (P. xanthochymum).

(b) Di hutan sekunder muda (Gambar 2b) jenis-jenis pohon menjulang dengan tinggi lebih dari $30 \mathrm{~m}$ hanya jenis meranti sapat ( $\mathrm{S}$. dasyphylla). Tinggi pohon antara 20-29 m didominasi oleh jenis pasir-pasir (P. xanthochymum), balam putih (M. ovata), jangkang (D. pulchella), medang merah (S. leprosula), dan terentang (C. auriculatum). Tinggi pohon kurang dari $20 \mathrm{~m}$ yaitu jenis asam kandis (G. nervosa), pisang-pisang (D. maingayi) dan asam kandis (G. nervosa).

(c) Di hutan belukar tua tidak ada pohon yang tingginya lebih dari $30 \mathrm{~m}$, tetapi yang ada tinggi pohon kurang dari 30 $\mathrm{m}$. Tinggi pohon antara 20-29 m yaitu jenis meranti bunga (S. teysmanniana), pisang-pisang (D. maingayi) dan pasir-pasir (P. xanthochymum), jambu-jambu (Eugenia sp.), meranti sapat (S. dasyphylla), dan pisang-pisang 
(D. maingayi). Tinggi pohon antara 15-20 m yaitu jenis meranti bunga ( $\mathrm{S}$. teysmanniana), jambu-jambu

(Eugenia sp.), punak (T. glabra) dan jambu-jambu (Eugenia sp.)

Ketiga kondisi hutan rawa-gambut tersebut menunjukkan bahwa strata tajuk jenis pasir-pasir (P. xanthochymum), meranti bunga (S. teysmanniana) dan pisang-pisang (D. maingayi) merupakan jenis yang menduduki strata dominan, diikuti jenis jangkang (D. pulchella), meranti sapat (S. gibbosa) dan meranti bunga (S. teysmanniana) tergolong strata kodominan. Menurut Samsoedin et al., (2014), strata pohon dominan merupakan pohon yang paling menjulang diantara pohon yang lain, kodominan adalah pohon tertinggi ke dua diantara pohon tersebut. Dengan demikian, jenis-jenis pohon berstrata dominan dan kodominan potensial untuk digunakan dalam pengkayaan jenis di kawasan hutan rawagambut tidak produktif. Karakteristik jenis tersebut merupakan jenis yang cocok dengan tempat tumbuhnya, sehingga mendominasi di ketiga kondisi hutan rawagambut tersebut. Hal ini dapat dijelaskan bahwa jenis tumbuhan yang dapat tumbuh/beradaptasi dengan baik di lingkungan gambut jumlahnya tidak terlalu banyak besar (Kartawinata, 2016). Penelitian Samsoedin \& Dharmawan, (2012) di Hutan Alam Malinau Kalimantan Utara, dominansi tinggi dikuasai oleh jenis yang menjulang (emergent) yaitu dari genus Shorea, Camnosperma dan Palaquium. Hal ini mirip dengan penelitian ini.

Gambar 3, dapat dikemukakan bahwa struktur tegakan hutan di lokasi penelitian menunjukkan jumlah pohon yang semakin berkurang dari kelas diameter kecil ke kelas diameter besar, sehingga bentuk kurva pada umumnya dicirikan oleh jumlah sebaran yang menyerupai "J" terbalik. Struktur tegakan hutan di lokasi penelitian menunjukkan karakteristik yang normal dalam pertumbuhan. Umumnya di hutan alam kelas diameter kecil lebih banyak dari kelas diameter besar (Samsoedin \& Heriyanto, 2010; Dharmanwan \& Samsoedin, 2012). Dalam hutan klimaks nilai kerapatan tinggi untuk jenis-jenis berdiameter kecil, yang juga menyum-bangkan kepada kekayaan jenis dalam petak, merupakan akibat gangguan pada masa lampau (Sheil, Kartawinata, Samsoedin, Priyadi, \& Afriastini, 2010; Rahmah, Kartawinata, Nisyawati, Wardhana \& Nurdin, 2016).

Jumlah permudaan di lokasi penelitian di hutan sekunder tua tingkat pancang jenis komersial sebesar 2.192 batang/ha, tingkat semai 12.800 batang/ha. Di hutan sekunder muda tingkat pancang jenis komersial sebesar 736 batang/ha, tingkat semai 6.200 batang/ha; di belukar tua tingkat pancang jenis komersial sebesar 640 batang/ha, tingkat semai 5.000 batang/ha. Ditinjau dari jumlah permudaan di lokasi penelitian telah memenuhi jumlah permudaan berdasarkan TPTI (Tebang Pilih Tanam Indonesia), yaitu tingkat pancang sebesar 400 batang/ha dan tingkat semai 2.500 batang/ha yang tersebar merata di hutan.

\section{Biomassa dan kandungan karbon}

Pada Tabel 4, terlihat bahwa biomassa dan kandungan karbon tegakan hutan yang berdiameter $10 \mathrm{~cm}$ ke atas di Kawasan Lindung Bukit Batu, Kabupaten Bengkalis, Provinsi Riau di hutan sekunder tua termasuk tinggi yaitu 304,50 ton/ha (152,25 ton $\mathrm{C} /$ ha setara dengan 558,76 ton $\mathrm{CO}_{2} /$ ha). Hasil penelitian ini lebih tinggi bila dibandingkan dengan Dharmawan, (2013) di hutan primer rawa-gambut Kalimantan Tengah sebesar 73,08 ton C/ha; di hutan sekunder rawa-gambut Kepulauan Meranti, Riau sebesar 37,9 ton C/ha dan di hutan sekunder rawa gambut Sumatera Selatan sebesar 29,1 ton C/ha (Rosalina et al., 2013).

Kerapatan tegakan berdiameter 10-20 $\mathrm{cm}$, tingkat pancang, dan tingkat semai di hutan rawa-gambut pada hutan sekunder tua berturut turut sebesar 382 pohon/ha, 
2.656 batang/ha dan 20.000 batang/ha. Hal ini menunjukkan bahwa kawasan hutan rawa gambut pada kondisi hutan sekunder tua mampu menyerap karbon dioksida yang tertinggi. Tingkat pohon di hutan sekunder tua didominasi oleh jenis pasirpasir/suntai (P. xanthochymum), dara-dara (G. paniculata) dan medang (Litsea sp.). Di hutan sekunder muda didominasi oleh jenis meranti sapat (S. dasyphylla), jambujambu (Eugenia sp.), dan dara dara (G. paniculata). Di belukar tua didominasi oleh pisang-pisang (D. maingayi), meranti bunga (S. teysmanniana) dan medang (L. firma).

Data biomassa suatu ekosistem sangat berguna untuk mengevaluasi pola produktivitas berbagai macam ekosistem yang ada (Chave et al., 2014). Tegakan hutan pada tingkat permudaan (tingkat tiang, pancang dan semai) berpotensi besar dalam menyerap kadar karbon dioksida di udara. Hal ini dapat dijelaskan bahwa pada pohon muda proses pertumbuhan relatif cepat dibanding dengan pohon yang sudah tua. Saat proses fotosintesis, maka karbon dioksida dan air diubah menjadi kabohidrat, selanjutnya melalui proses metabolisme menjadi lipid, asam nukleat, dan protein, bahan ini yang akan diubah menjadi organ tumbuhan (Widhi \& Murti, 2014).

\section{KESIMPULAN DAN SARAN}

\section{A. Kesimpulan}

Hutan Rawa-Gambut Bukit Batu, Kabupaten Bengkalis, Provinsi Riau pada kondisi hutan sekunder tua tercatat 40 jenis pohon dengan $22 \mathrm{suku}$, di hutan sekunder muda terdapat 45 jenis dengan 18 suku, dan di hutan belukar tua ada 35 jenis dengan 20 suku. Ketiga kondisi hutan rawa gambut tersebut menunjukkan jumlah pohon inti dan permudaan jenis komersial sudah mencukupi. Di hutan sekunder tua pada tingkat pohon didominasi oleh jenis pasir-pasir/suntai (P. xanthochymum), dara-dara (G. paniculata) dan medang
(Litsea sp.). Di hutan sekunder muda didominir oleh jenis meranti sapat (S. dasyphylla), jambu-jambu (Eugenia sp.), dan dara-dara (G. paniculata). Di belukar tua didominasi jenis pisang-pisang (D. maingayi), meranti bunga (S. teysmanniana) dan medang (L. firma). Jenis yang mendominasi regenerasi lengkap (tingkat pohon, pancang dan semai) yang menyebar di setiap lokasi yaitu jenis dara-dara (G. paniculata), arang-arang (D. Siamang) dan jambujambu/kelat (Eugenia $\mathrm{sp}$.). Biomassa dan kandungan karbon tegakan hutan yang berdiameter $10 \mathrm{~cm}$ ke atas di hutan sekunder tua yaitu sebesar 302,29 ton/ha (151,14 ton $\mathrm{C} /$ ha setara dengan 554,70 ton $\mathrm{CO}_{2} /$ ha). Di hutan sekunder muda sebesar 86,86 ton/ha $(43,42$ ton C/ha setara dengan 159,38 ton $\mathrm{CO}_{2} /$ ha). Di belukar tua sebesar 72,75 ton/ha $(36,37$ ton $\mathrm{C} /$ ha setara dengan 133,50 ton $\left.\mathrm{CO}_{2} / \mathrm{ha}\right)$.

\section{B. Saran}

Pohon yang potensial dijadikan sumber benih dari hutan rawa-gambut di Kawasan Hutan Lindung Bukit Batu, Kabupaten Bengkalis, Provinsi Riau adalah pohon pasir-pasir/suntai (P. xanthochymum), meranti sapat (S. dasyphylla) dan pisang-pisang (D. maingayi). Hutan rawa-gambut tersebut perlu perlindungan dari kebakaran dan perambahan.

\section{UCAPAN TERIMA KASIH}

Dalam pelaksanaan penelitian ini penulis mengucapkan banyak terima kasih kepada (1) Saudara Eman teknisi Litkayasa Penyelia pada Puslitbang Hutan, Bogor yang membantu mengolah data, (2) segenap Direksi PT Asia Pulp and Paper dan Sinar Mas Group Indonesia. 


\section{DAFTAR PUSTAKA}

Arbainsyah., De longh, H.H., \& Kustiawan, W. (2014). Structure, composition and diversity of plant communities in FSC-certified, selectively logged forests of different ages compared to primary Rain Forest. Biodiversity Conservation, 23(10), 24-45.

[BPS] Badan Pusat Statistik. (2018). Bengkalis Dalam Angka. Badan Pusat Statistik Kabupaten Bengkalis. Provinsi Riau.

Chave, J., Mechain, M.R., Burqueez, A., Chidumayo, E., Colgan, M.S., Delitti, W.B.C., Dugue, A., Eid, T., Fearnside, P.M., Goodman, R.C., Henry, M., Yrizar, A.M., Mugasha, W.A., Landau, H.C.M., Mencuccini, M., Nelson, B.W., Ngomanda, A., Noguiera, E.M., Malavessi, E.O., Pelissier, R., Ploton, P., Ryan, C.M., Soldarriaga, J.G. \& Vieilledent, G. (2014). Improved allometric models to estimate the aboveground biomass of tropical trees. Global Change Biology (2014), doi: 10.1111/ gcb.12629

Dharmawan, I.W.S., \& Samsoedin, I. (2012). Dinamika potensi biomassa karbon pada landskap hutan bekas tebangan di Hutan Penelitian Malinau. Jurnal Penelitian Sosial dan Ekonomi Kehutanan, 9(1), 12-20.

Dharmawan, I.W.S. (2012). Evaluasi Dinamika Cadangan Karbon Tetap pada Hutan Gambut Primer dan Bekas Terbakar di Hampangen dan Kalampangan, Kalimantan Tengah. Desertasi Doktor. Sekolah Pasca Sarjana IPB, Bogor.

Heriyanto, N.M., Samsoedin, I., \& Kartawinata, K. (2019). Trre species diversity, structural characteristics and carbon stock in a one-hectare plot of the protection forest area in West Lampung Regency, Indonesia. Reinwardtia, 18(1), 1-18.
Heriyanto, N.M., Samsoedin, I., \& Bismark, M. (2019). Keanekaragaman hayati flora dan fauna di Kawasan Hutan Bukit Datuk Dumai Provinsi Riau. Jurnal Sylva Lestari, 7(1), 82-94.

High Carbon Stock/HCS Approach. (2017). Pendekatan Stok Karbon Tinggi Mempraktekkan Nihil Deforestasi. The HCS Approach Toolkit, Module 4, Version 2.0. Kuala Lumpur, HCS Approch Steering Group.

[IPCC] International Panel on Climate Change. (2013). Climate change 2013 the physical basis working group I contrubution to the fifth assessment report of the IPCC. Switzerland.

[INCAS] Indonesia National Carbon Accounting System. (2015). Indonesia Luncurkan Alat Baru Hadapi Perubahan Iklim. Program REDD-I. Hutan dan Perubahan Iklim di Indonesia. Kementerian Lingkungan Hidup dan Kehutanan Indonesia.

Kartawinata, K. (2016). Diversitas Ekosistem Alami Indonesia. Cetakan ke-2, Penerbit: Yayasan Pustaka Obor Indonesia.

Laumonier, Y., Uryu, Y., Stuwe, M., Budiman, A., Setiabudi, B., \& Hadian, O. (2010). Eco-floristic sectors and deforestation threats in Sumatra: identifying new conservation area network priorities for ecosystem-based land use planning. Biodivers Conserv, 19, 1153-1174. DOI: $10.1007 / \mathrm{s} 10531-$ 010-9784-2.

Masganti, Wahyunto., Dariah., A., Nurhayati, \& Yusuf, R., (2014). Karakteristik dan potensi pemanfaatan lahan gambut terdegradasi di Provinsi Riau. Jurnal Sumberdaya Lahan, 8, 47-54.

Mueller-Dombois, \& Ellenberg. (2016). Ekologi vegetasi: Tujuan dan Metode (Terjemahan Aims and Methods of Vegetation Ecology oleh Kartawinata, 
K., \& Abdulhadi, R.). LIPI Press \& Yayasan Pustaka Obor. Jakarta.

Nurhayati, A.D., Aryanti, E., \& Saharjo, B.H., (2010). Kandungan emisi gas rumah kaca pada kebakaran hutan rawa-gambut di Pelalawan Riau. Jurnal Ilmu Pertanian Indonesia, 15(2), 78-82.

Purwanta, W. (2010). Penghitungan emisi karbon dari lima sektor pembangunan berdasar metode IPCC dengan verifikasi faktor emisi dan data aktivitas lokal. Jurnal Teknologi Lingkungan, 11(1), 71-77.

Rahmah, K. Kartawinata, Nisyawati, Wardhana, \& Nurdin, E. (2016). Tree species diversity in the lowland forest of the core zone of the Bukit Duabelas National Park, Jambi, Indonesia. Reinwardtia, 15(1), 11-26.

Ripin, Astiani, D., \& Burhanuddin. (2017). Jenis-jenis pohon penyusun vegetasi hutan rawa- gambut di Semenanjung Kampar Kecamatan Teluk Meranti Provinsi Riau. Jurnal Hutan Lestari, 5(3), 807-813.

Rosalina, Y., Kartawinata, K., Nisyawati, Nurdin, E., \& Supriatna, J. (2013). Kandungan karbon di hutan rawagambut kawasan konservasi PT National Sago Prima, Kepulauan Meranti, Riau. Buletin Kebun Raya, 16(2), 115-130.

Rosalina, Y., Kartawinata, K., Nisyawati, Nurdin, E., \& Supriatna, J. (2014). Floristic composition and structure of a peat swamp forest in the conservation area of the PT National Sago Prima, Selat Panjang, Riau, Indonesia. Reinwardtia. 14(1), 193210.

Sadili, A., Kartawinata, K., Soedjito, H. \& Sambas, E. (2018) Tree species diversity in a pristine montane forest previously untouched by human activities in Foja Mountains, Papua, Indonesia. Reinwardtia, 17(2), 133154.
Samsoedin, I., \& Heriyanto, N.M. (2010). Struktur dan komposisi hutan pamah bekas tebangan ilegal di kelompok hutan Sei Lepan, Sei Serdang, Taman Nasional Gunung Leuser, Sumatera Utara. Jurnal Penelitian Hutan dan Konservasi Alam, 8(3), (299-314.

Samsoedin, I., Heriyanto, N.M., \& Bismark, M. (2014). Keanekaragaman hayati flora dan fauna di kawasan hutan Pertamina Bukit Datuk Dumai, Provinsi Riau. Jurnal Penelitian Hutan dan Konservasi Alam, 11(1), 77-89.

Sheil, D., Kartawinata, K., Samsoedin, I., Priyadi, H., \& Afriastini, J.J. (2010). The lowland forest tree community in Malinau, Kalimantan (Indonesian Borneo): results from a one-hectare plot. Plant Ecology \& Diversity, 3(1), 59-66.

Supriadi, A., \& Abdurachman. (2018). Sifat pemesinan lima jenis kayu asal Riau. Jurnal Penelitian Hasil Hutan, 36(2), 85-100.

The Plant List. (2013). The Plant List Version 1.1. Royal Botanic Gardens, Kew, U.K. and Missouri Botanical Garden, Missouri, U.S.A.

Wahyunto, Dariah, Pitono \& Sarwani. (2013). Prospek pemanfaatan lahan gambut untuk perkebunan kelapa sawit di Indonesia. Perspektif, 12(1),11-12.

Wardani, M., Astuti, I..P., \& Heriyanto, N.M. (2017). Analisis vegetasi jenisjenis Dipterocarpaceae di kawasan hutan Seksi I Way Kanan, Taman Nasional Way Kambas, Lampung. Buletin Kebun Raya, 20(1), 51-64.

Widhi S.J.K, \& Murti, S.H. (2014). Estimasi stok karbon hutan dengan memanfaatkan citra landsat 8 di Taman Nasional Tesso Nilo, Riau. Jurnal Bumi Indonesia, 3(2), 1-11

Yuniawati. (2013) Pengaruh pemanenan kayu terhadap potensi karbon tumbuhan bawah dan serasah di lahan gambut (Studi kasus di areal 
Keanekaragaman Hayati dan Rosot Karbon pada Rawa-Gambut di Bukit Batu,

Kabupaten Bengkallis, Provinsi Riau N.M Heriyanto, Dolly Priatna, dan/and Ismayadi Samsoedin

HTI kayu serat PT RAPP Sektor Pelalawan, Provinsi Riau). Jurnal Hutan Tropis, 1(1), 24-31. 